\title{
The Effects of Global Liquidity on Global Imbalances
}

\author{
Marie-Louise DJIGBENOU-KRE* \\ Hail Park**
}

The views expressed herein are those of the authors and do not necessarily reflect the official views of the Bank of Korea. When reporting or citing this paper, the authors' names should always be explicitly stated.

\footnotetext{
* Economist, Banque de France and University Montesquieu Bordeaux IV.

** Dr. Park is a former senior economist at the Bank of Korea and is currently an assistant professor at Kyung Hee University. E-mail: hailpark@khu.ac.kr.

This joint paper was completed while Dr. Park was working for the Bank of Korea. The views expressed herein are those of the authors and do not necessarily reflect the official views of the Bank of Korea and the Banque de France.
}

We are grateful for the helpful comments and suggestions from Woon Gyu Choi, Jin-Su Park, Geun-Young Kim. We also wish to thank the seminar participants at the Bank of Korea. 


\section{Contents}

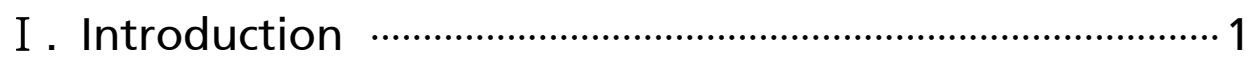

II. US Monetary Shock and Amplified Global Liquidity

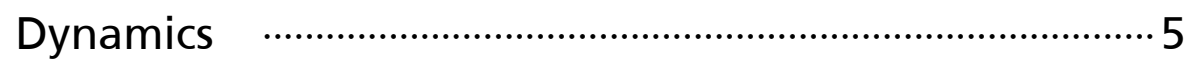

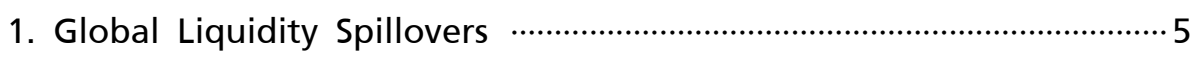

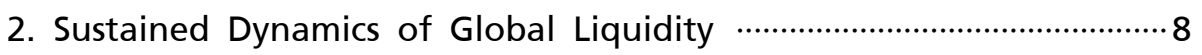

III. Global Liquidity and Global Imbalances …………......11

1. Why the Linkage?

2. Global Liquidity Heightens Global Imbalances? ……………………...13

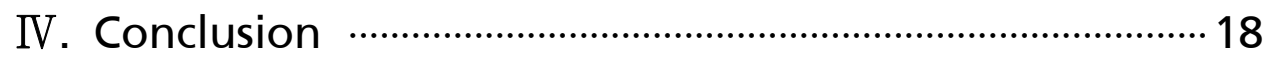

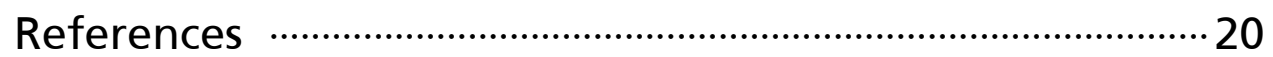




\section{The Effects of Global Liquidity on Global Imbalances}

This paper examines how global liquidity responds to a US (United States) monetary policy shock, and whether global liquidity has effects on global imbalances. To this end we estimate regression and Panel-VARX models using data from the G5 (US, United Kingdom, Euro area, Japan and Canada) and 20 emerging countries. The empirical results show that global liquidity is meaningfully affected by a US monetary shock, and that the effects on global imbalances of global liquidity are significant. The foreign exchange reserves of emerging economies are also found to play a significant role related to global imbalances.

Keywords: Global liquidity, Global imbalances, Panel-VARX, US monetary shock, Spillover effect

JEL Classification: E51, F30, F33 


\section{I . Introduction}

Global liquidity in monetary terms has increased significantly in recent years. Private agents, economists and researchers as well as central banks and international institutions are becoming increasingly interested in this phenomenon. This increased interest in global liquidity has been driven first of all by the period of excess liquidity prior to the outbreak of the global financial crisis. And this excess liquidity has come both from the liquidity provided by official authorities and the liquidity from financial institutions and markets. More recently, the interest has been motivated in essence by the accommodative policies adopted by monetary authorities with their expanded use of unconventional measures. At the same time, the liquidity issued by banks and some markets has continued to slow. This dynamic of global liquidity continues to intrigue us, especially because its impacts on the international economy and financial system are not well known.

In this regard, the IMF (2013) has tried to conduct surveillance of the dynamics. The BIS also shares this logic and is already providing some indicators. One main indicator highlighted by both institutions to this end is interbank flows, as this is a channel used by financial agents to transfer liquidity from the monetary to other areas. But this liquidity and the management of the funds are highly dependent on the monetary policy implemented by the local monetary authorities. Looking for instance at the key policy interest rates of central banks, a global downward trend has been observed since the global financial crisis. These policy rate decisions are without doubt justified by the objectives of the monetary authorities. According to Djigbenou (2013), global liquidity is essentially guided by the real economic situation and financial stability. And the recent experiences with implementation of the US Federal Reserve's quantitative easing (QE) policy illustrate these purposes. The low key policy rate of the European Central Bank, in a context of deflation risk, could also be explained by these economic motivations. But even if they are justified, accommodative domestic policies in advanced economies (AEs) could also significantly affect the dynamics of liquidity in the world as a whole. 
In this paper, we focus essentially on a monetary definition of global liquidity, especially on that issued by monetary authorities. Basically, global liquidity can be considered as the monetary aggregates provided by domestic agents (in this case, mainly monetary authorities), which can be used outside their own monetary areas for buying goods, services or assets. Accordingly, the dynamics of global liquidity are strongly linked to the monetary liquidity provided by advanced countries. The monetary liquidity issued by the US Federal Reserve, the European Central Bank, the Bank of England, the Bank of Japan and the Bank of Canada can be directly used outside their own monetary areas in the international trade and financial markets. Therefore, they contribute directly to the growth or decline of global liquidity, particularly by reallocations of their domestic liquidity throughout the world thus increasing liquidity in different economies and markets. The monetary policies adopted by these advanced country central banks during the recent crisis have been favorable to increased global liquidity. In the meantime, the global liquidity dynamics are not based solely on the liquidity provided by advanced countries, but may also be affected by liquidity from emerging market economies (EMEs). For instance, some regional trades in Latin America or in Asia are in local currencies. However, the currencies of the main advanced countries remain the most used and the most liquid.

In general, each monetary authority defines its own monetary policy in accordance with its objectives and its economic situation. Considering the evolution of interest rates, the dynamics of global liquidity seem to have followed a self-sustaining process. For example, the monetary policy tightening adopted by the US Federal Reserve in 2004 by itself slowed overall global liquidity growth. A few quarters later, other central banks adopted monetary tightening policies, which in their turn also contributed to the slowdown of global liquidity growth. A similar mechanism can be observed as well in an accommodative framework. As in the previous case, the accommodative policy of the US Fed was followed by accommodative policies of other central banks. This strong correlation between the liquidity issued by the Fed and that by other central banks could lead to questions about the spillover effects of a domestic liquidity policy to the global liquidity dynamics, especially after a modification of US monetary policy. What are the spillover effects of such a change in US monetary policy on global liquidity? 


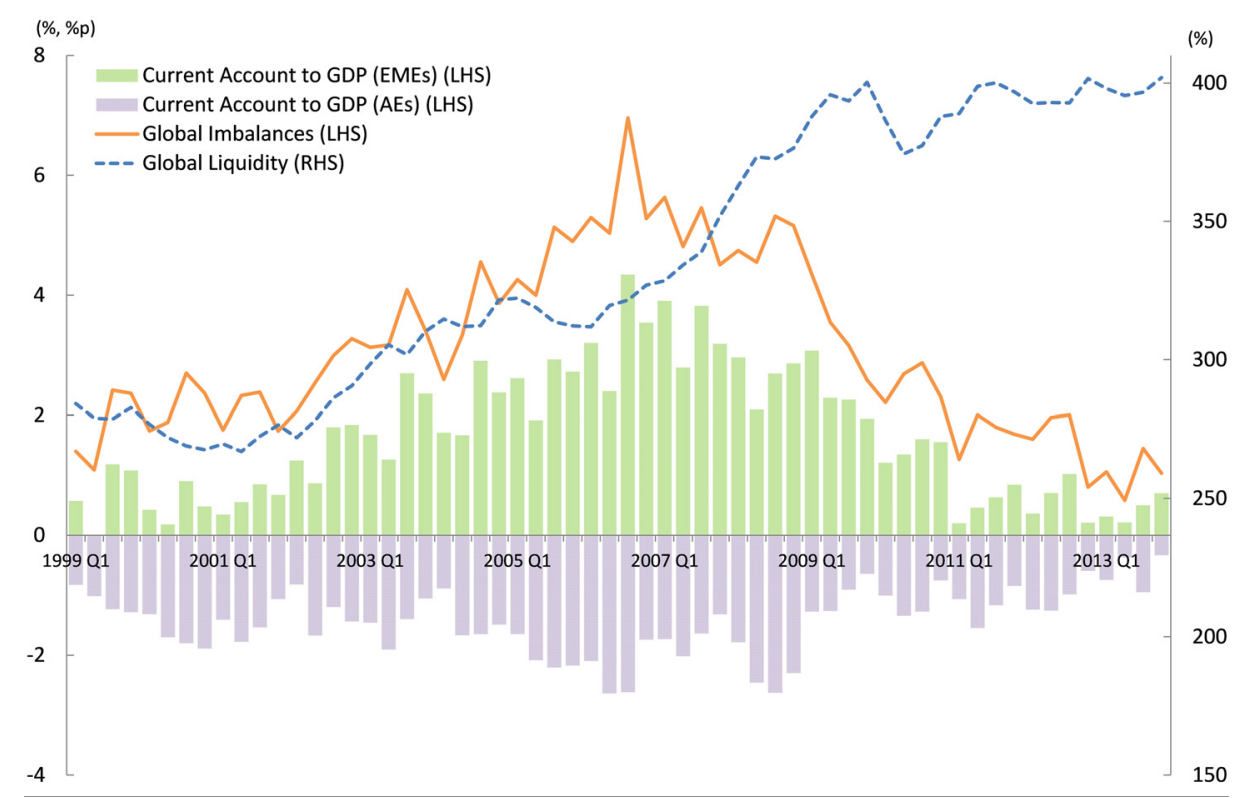

Notes: Global Liquidity is defined as the M2-to-GDP ratio in AEs. In the case of the UK, M4 is used instead of M2. Global imbalances are calculated as the sum of the absolute values of the aggregate current account-to-GDP ratios of EMEs and of AEs. AEs (5): United States, United Kingdom, Euro Area, Japan, Canada. EMEs (20): Argentina, Brazil, Chile, Mexico, Peru, Czech Republic, Hungary, Poland, Russia Federation, Turkey, China, India, Indonesia, South Korea, Malaysia, Philippines, Singapore, Thailand, Israel, South Africa.

Source: IMF International Financial Statistics.

In this context, the global liquidity dynamics and global imbalances seem to be mutually related. It is obvious that periods of slowdown in global liquidity growth are followed by decreases in global imbalances. According to Figure 1, advanced economies have in the past 15 years shown large deficits in their current accounts, whereas emerging market economies have recorded substantial current accounts surpluses. Obviously, AEs' current account deficits have been offset by surpluses in their capital and financial accounts, since EMEs have invested their funds in AEs (Chung et al., 2014). Moreover, the rise in global liquidity in the run-up to the global financial crisis of 2008 appears to have been associated with the increase in global imbalances during that time. But global imbalances have shown a narrowing trend and been stabilized since the crisis, with the stable movements in global liquidity. 
There have been various causes of global imbalances proposed in other studies. These include: the global saving glut (Bernanke 2005, 2007), foreign exchange market interventions in emerging economies (Dooley et al., 2004), preference for safe assets of advanced countries (Caballero, 2006; Caballero et al., 2008), capital flows from emerging to developed countries, dubbed the "uphill flow of capital" (Gagnon, 2012), and negative savings-investment gaps and over-consumption in advanced countries due to persistent monetary policy easing (Cooper, 2006; Feldstein, 2008). Even though global imbalances are attributable to a wide range of factors, we focus here on the effects of global liquidity on them. Barnett and Straub (2008) showed that monetary policy shocks played a crucial role in current account deteriorations in the US from 1970 to 2006, through a structural VAR model including output, inflation, the interest rate, oil price inflation, the current account, the sum of consumption and investment, and the real effective exchange rate. In terms of the forecast error variance decomposition, monetary policy shocks accounted for over 60 percent of it at a one-year forecast.

The main purpose of this paper is to study in its first part how global liquidity responds to a US monetary policy shock, and in its second part the effects of global liquidity on global imbalances. To answer these questions, we estimate regression and Panel-VARX models. Our study concerns 25 countries: five advanced (United States, United Kingdom, Euro area, Japan and Canada) and 20 emerging market (Argentina, Brazil, Chile, Mexico, Peru, Czech Republic, Hungary, Poland, Russia Federation, Turkey, China, India, Indonesia, South Korea, Malaysia, Philippines, Singapore, Thailand, Israel and South Africa) economies, for the period from 1999 to 2013.The results of this study suggest that the dynamics of global liquidity are amplified after a US monetary shock, and that global liquidity has significant effects on global imbalances. Global liquidity tends to display proportionally greater dynamics than those following the initial US monetary shock and considerably affects the imbalances in the global economy. The foreign exchange reserves of emerging economies also play a significant role driving global imbalances. We organize this paper as follows. Section 2 examines the dynamics of global liquidity due to a US monetary policy shock. In Section 3, we empirically study whether there are any significant effects of global liquidity on global imbalances. Section 4 then concludes. 


\section{II . US Monetary Shock and Amplified Global Liquidity Dynamics}

Global liquidity is regarded in this paper as the sum of the broad monetary aggregates (M2 or M4) in advanced countries (US, UK, Euro area, Japan and Canada). In other words, it represents the sum of the domestic monetary liquidity provided by advanced countries able to export their local currencies outside their own monetary areas. Global liquidity thus depends upon the policies adopted by these advanced countries' monetary authorities. It would be interesting to understand the relationship between an individual monetary policy shock, especially a US shock, and the dynamics of global liquidity. Interest rate parity within the framework of Mundell's trilemma explains a self-sustaining dynamics, which is supported by the empirical data.

\section{Global Liquidity Spillovers}

Mundell's trilemma, or incompatibility triangle, describes a constrained relationship between exchange rates, monetary policy and capital flows. It refers to the impossibility of having perfect capital flow mobility, an autonomous monetary policy and a fixed exchange rate at the same time. The interest rate cannot serve both an external and an internal objective in an environment of perfect capital flow mobility. It is in this context that monetary authorities make their decisions, and the dynamics of global liquidity thus also depend upon these relationships.

Let us consider an accommodative monetary shock following a cut in its policy interest rate by one economy, as it affects another economy. Other things remaining equal this policy shock increases the interest rate differential between the two countries de facto, and thus heightens the attractiveness of capital flows. This fosters appreciation of the currency of the second country, reducing its price competitiveness. In order to limit the negative impacts on its real economy and bubbles in its financial markets, and to avoid sudden and massive outward capital flows, the monetary authorities in the second country are thus driven to cut their 
key interest rate as well. The interest rate differential between the two countries then returns to the initial equilibrium.

This is also the case when the monetary policy adopted by a central bank is non-conventional. In this framework, the shock caused by the first country has impacts on prices and returns in the markets. To rebalance their portfolios, investors then redefine the components to sustain their risk-return ratios. Considering that agents diversify their portfolios in local and foreign assets, the rebalancing of their portfolios brings about capital flows in the direction of the second country. The second country is then faced with an appreciation of its currency and expanded capital in its financial markets. At this stage, its monetary authorities can allow the markets to self-correct in the long run, through a progressive decline in market returns and the effects of currency appreciation, or they can react in the short run with accommodative policy. The liquidity shock caused by one country can therefore induce reactions from other countries, and in this way cause an increase in global liquidity greater than the initial shock.

These mechanisms between domestic monetary policies and the dynamics of global liquidity are illustrated by Figure 2, where three groups of countries are considered. Group 1 comprises the United States (US) alone. In this model, US monetary policy is considered as the initial shock, because of the US dollar's key role in the international financial system. Ehrmann and Fratzscher (2009) show the crucial role of a US monetary policy shock in the global financial markets, and Kazyi et al. (2013) study its significant impacts on GDP growth in different countries. Moreover, as mentioned in the introduction, over the recent period US monetary shocks have been observed first, prior to others. The second group in Figure 2 is the group of other advanced countries - the United Kingdom (UK), the Euro area (EA), Japan (JP) and Canada (CN). The third group, finally, is made up of emerging market economies.

A US monetary shock could induce lower policy interest rates or unconventional measures in other countries, in their efforts to limit the effects of the shock on their currencies and thus on their economies. Over the recent period, this consideration of the exchange rate in monetary policy can be observed for instance in the case of the direct foreign exchange market 
Figure 2: US Monetary Shock and Global Liquidity Spillovers

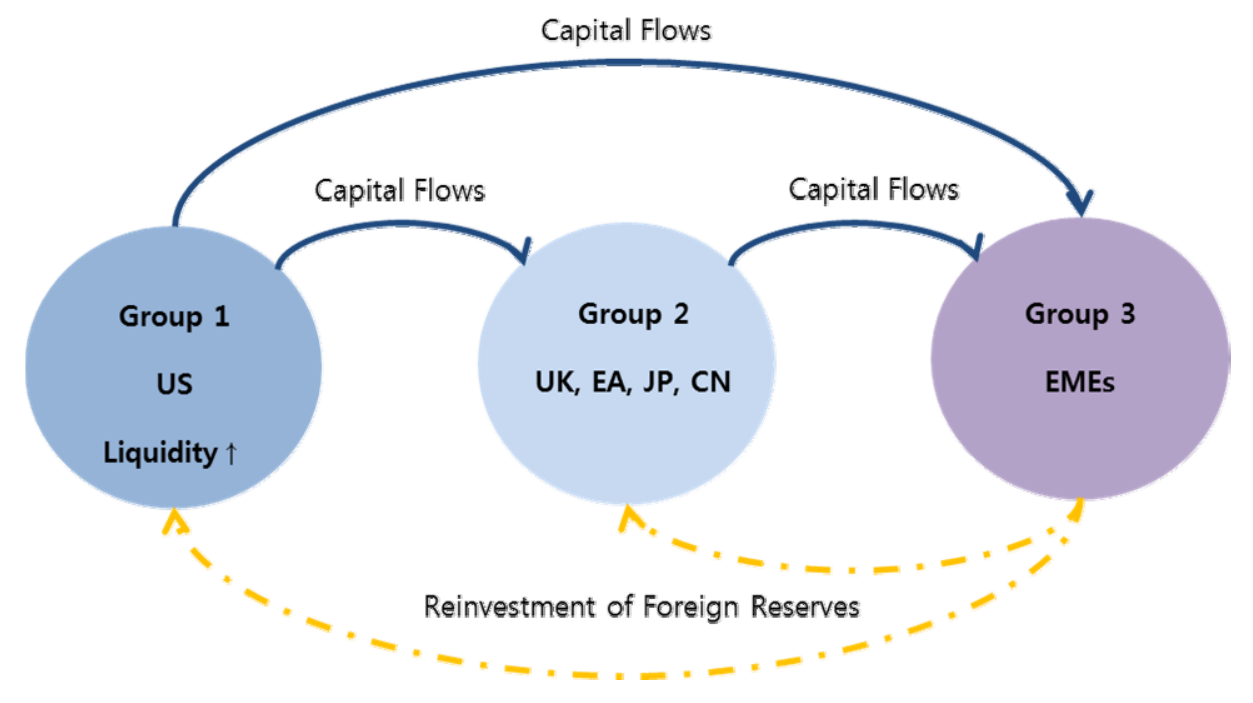

intervention by the Bank of Japan to reduce the yen's appreciation against the USD. More recently, ECB Governor Draghi has stated that "the exchange rate is not a policy target for the ECB. The target for the ECB is medium-term price stability. However, the exchange rate is important for growth and for price stability and we certainly pay close attention to these developments" (Draghi and Constâncio, 2013). Taking into account exchange rates movements could thus contribute to justify accommodative monetary policies in different countries and therefore cause global liquidity to increase. In Group 3, the influence of a US monetary shock leads to the accumulation of foreign exchange reserves.

In fact, the appreciations of other currencies due to accommodative US policy affect the foreign exchange reserves of emerging countries through different channels. First of all, they can have direct effects on emerging country current accounts. To mitigate appreciations of their currencies, central banks in emerging economies intervene in their foreign exchange markets and accumulate foreign exchange reserves. The effects of the accommodative US policy on emerging countries' foreign reserves can also move through the financial channel or through the internal networks of global banks (Bruno and Shin, 2013). Via carry 
trade operations, a shock from US monetary easing could be taken advantage of to acquire more foreign assets or to fund projects having more attractive interest rates, through the improved conditions of banks' overseas branch offices. These different channels can drive the USD into emerging countries and increase their foreign exchange reserves, which can be either sterilized or not. If a country does not sterilize, then the entry of foreign currencies corresponds directly to an increase in local liquidity. But, whatever the case, the buildup of foreign reserves can be reinvested in different markets and therefore provide more liquidity to these markets. These reinvestments thus expand liquidity in the markets concerned, and decrease returns. In this way, global liquidity is increased due to an unconventional monetary policy.

Global liquidity can thus display a snowballing dynamics, to the extent that one accommodative monetary shock can cause chain reactions that can also boost global liquidity. An empirical study could give us a better understanding of the dynamics of global liquidity.

\section{Sustained Dynamics of Global Liquidity}

As explained previously, the global liquidity dynamics are amplified if other countries react to a monetary policy shock. Depending upon the main objectives of the monetary authorities, monetary policy responds basically to real activity and price stability. Thus, similarly to in the Taylor rule, the liquidity of country i, $L I Q_{i}$, is defined here as a linear function of real activity $G D P_{i}$ and inflation $C P I_{i}$, expressed in terms of quarterly growth rates (equation (1)), and global liquidity (GLIQ) as a simple sum of the liquidity of $\mathrm{n}$ countries (equation (2)):

$$
\begin{gathered}
L I Q_{i, t}=\alpha_{0}+\alpha_{1} L I Q_{i, t-1}+\alpha_{2} G D P_{i, t-1}+\alpha_{3} C P I_{i, t-1}+\epsilon_{i, t} \\
G L I Q_{t}=\sum_{i=1}^{n} L I Q_{i, t}
\end{gathered}
$$

To study the dynamics of global liquidity following a monetary shock, especially from the US, we extend the basic domestic monetary rule by including 
the US monetary shock inside the decision rule for other advanced countries (UK, $\mathrm{EA}, \mathrm{JP}$ and $\mathrm{CN})$ :

$$
\begin{aligned}
L I Q_{U S, t}= & \alpha_{U S, 0}+\alpha_{U S, 1} L I Q_{U S, t-1}+\alpha_{U S, 2} G D P_{U S, t-1}+\alpha_{U S, 3} C P I_{U S, t-1}+\epsilon_{U S, t} \\
L I Q_{U K, t}= & \alpha_{U K, 0}+\alpha_{U K, 1} L I Q_{U K, t-1}+\alpha_{U K, 2} G D P_{U K, t-1}+\alpha_{U K, 3} C P I_{U K, t-1}+\beta_{U K, 1} L I Q_{U S, t}+ \\
& \beta_{U K, 2} L I Q_{U S, t-1}+\epsilon_{U K, t} \\
L I Q_{E A, t}= & \alpha_{E A, 0}+\alpha_{E A, 1} L I Q_{E A, t-1}+\alpha_{E A, 2} G D P_{E A, t-1}+\alpha_{E A, 3} C P I_{E A, t-1}+\beta_{E A, 1} L I Q_{U S, t}+ \\
& \beta_{E A, 2} L I Q_{U S, t-1}+\epsilon_{E A, t} \\
L I Q_{J P, t}= & \alpha_{J P, 0}+\alpha_{J P, 1} L I Q_{J P, t-1}+\alpha_{J P, 2} G D P_{J P, t-1}+\alpha_{J P, 3} C P I_{J P, t-1}+\beta_{J P, 1} L I Q_{U S, t}+ \\
& \beta_{J P, 2} L I Q_{U S, t-1}+\epsilon_{J P, t} \\
L I Q_{C N, t}= & \alpha_{C N, 0}+\alpha_{C N, 1} L I Q_{C N, t-1}+\alpha_{C N, 2} G D P_{C N, t-1}+\alpha_{C N, 3} C P I_{C N, t-1}+\beta_{C N, 1} L I Q_{U S, t}+ \\
& \beta_{C N, 2} L I Q_{U S, t-1}+\epsilon_{C N, t}
\end{aligned}
$$

From equation (2), we get the sum of the changes in domestic liquidity of the G5 countries as follows:

$$
\Delta G L I Q=\Delta L I Q_{U S}+\Delta L I Q_{U K}+\Delta L I Q_{E A}+\Delta L I Q_{J P}+\Delta L I Q_{C N}
$$

The change in global liquidity is then written as

$$
\Delta G L I Q=\left(1+\beta_{U K}+\beta_{E A}+\beta_{J P}+\beta_{C N}\right) \Delta L I Q_{U S}+\Delta \widetilde{L I Q_{U K}}+\Delta L \widetilde{I Q_{E A}}+\Delta \widetilde{L I Q_{C N}},
$$

where $\Delta \widetilde{L I Q}_{i}$ denotes the change in domestic liquidity of country i without the US monetary shock.

If the monetary authorities of other advanced economies react to the US monetary shock, i.e. if in this case $\beta_{U K}, \beta_{E A}, \beta_{J P}$ and $\beta_{C N}$ are significant, then we 
Table 1: Regression Results

\begin{tabular}{|c|c|c|c|c|}
\hline VARIABLES & $\begin{array}{c}(1) \\
\Delta L I Q_{-} U K\end{array}$ & $\begin{array}{c}(2) \\
\triangle L I Q \_E A\end{array}$ & $\begin{array}{c}(3) \\
\Delta L \mid Q_{-} J P\end{array}$ & $\begin{array}{c}\text { (4) } \\
\triangle \mathrm{LIQ} C \mathrm{CN}\end{array}$ \\
\hline$\triangle \mathrm{LIQ}$ US & $\begin{array}{c}0.546 \\
{[0.550]}\end{array}$ & $\begin{array}{l}-0.774 \\
{[0.476]}\end{array}$ & $\begin{array}{c}-0.564^{* *} \\
{[0.044]}\end{array}$ & $\begin{array}{l}0.549^{* *} \\
{[0.027]}\end{array}$ \\
\hline$\triangle L I Q \_U S(-1)$ & $\begin{array}{c}0.348 \\
{[0.281]}\end{array}$ & $\begin{array}{c}0.335 \\
{[0.765]}\end{array}$ & $\begin{array}{c}0.833^{* * *} \\
{[0.000]}\end{array}$ & $\begin{array}{c}0.163 \\
{[0.232]}\end{array}$ \\
\hline$\triangle L \mid Q_{-} U K(-1)$ & $\begin{array}{c}0.039 \\
{[0.557]}\end{array}$ & & & \\
\hline$\triangle G D P \_U K$ & $\begin{array}{c}-5.879^{* * *} \\
{[0.006]}\end{array}$ & & & \\
\hline$\triangle \mathrm{CPI} U \mathrm{UK}$ & $\begin{array}{c}5.325 \\
{[0.489]}\end{array}$ & & & \\
\hline$\triangle L_{1} \_E A(-1)$ & & $\begin{array}{l}0.280^{* *} \\
{[0.011]}\end{array}$ & & \\
\hline$\triangle G D P_{-} E A$ & & $\begin{array}{l}-0.764 \\
{[0.862]}\end{array}$ & & \\
\hline$\triangle$ CPI_EA & & $\begin{array}{l}-3.987 \\
{[0.589]}\end{array}$ & & \\
\hline$\triangle L I Q \_J P(-1)$ & & & $\begin{array}{c}0.100 \\
{[0.176]}\end{array}$ & \\
\hline$\triangle G D P \_J P$ & & & $\begin{array}{c}-2.623^{* * *} \\
{[0.000]}\end{array}$ & \\
\hline$\triangle$ CPI_JP & & & $\begin{array}{c}0.877 \\
{[0.432]}\end{array}$ & \\
\hline$\triangle \mathrm{LIQ} \_\mathrm{CN}(-1)$ & & & & $\begin{array}{c}-0.244^{* *} \\
{[0.046]}\end{array}$ \\
\hline$\triangle \mathrm{GDP} \_\mathrm{CN}$ & & & & $\begin{array}{l}-0.561 \\
{[0.190]}\end{array}$ \\
\hline$\triangle \mathrm{CPI} C \mathrm{CN}$ & & & & $\begin{array}{c}-2.606^{* * *} \\
{[0.000]}\end{array}$ \\
\hline Constant & $\begin{array}{c}0.075 \\
{[0.981]}\end{array}$ & $\begin{array}{l}3.763^{*} \\
{[0.088]}\end{array}$ & $\begin{array}{l}3.340^{* * *} \\
{[0.000]}\end{array}$ & $\begin{array}{l}0.746^{*} \\
{[0.055]}\end{array}$ \\
\hline $\begin{array}{c}\text { Adjusted R-squared } \\
\text { D-W Stat. }\end{array}$ & $\begin{array}{l}0.101 \\
1.974\end{array}$ & $\begin{array}{l}0.004 \\
1.940\end{array}$ & $\begin{array}{l}0.517 \\
1.946\end{array}$ & $\begin{array}{l}0.362 \\
2.026\end{array}$ \\
\hline
\end{tabular}

Notes: Newey-West standard errors in brackets. *** $p<0.01,{ }^{* *} p<0.05,{ }^{*} p<0.1$

consider that their central banks integrate the US monetary shock in their monetary decisions. In addition, if these coefficients are positive, then global liquidity has a self-sustaining dynamics. To estimate these regressions, we consider the first differenced quarterly data of variables from 1999 q1 to $2013 q 4$. Liquidity is defined as the ratio of M2 to nominal GDP, and all data are extracted from the IMF IFS database. ${ }^{1)}$ If the results for other advanced countries following a US

1) As has been mentioned, M4 is used in the case of the UK. 
monetary shock are found to be significantly positive, then we consider that the dynamic of global liquidity can be amplified after a US monetary shock due to the responses of other advanced countries. The results of these regressions are summarized in Table 1.

The results show the responses of JP and $\mathrm{CN}\left(\beta_{J P, 2}\right.$ and $\left.\beta_{C N, 1}\right)$ to a US monetary shock to be significantly positive (columns (3) and (4)). That means that the additional liquidity provided initially by the US monetary authority can amplify liquidity in both countries. In contrast, $\beta_{U K}$ and $\beta_{E A}$ are statistically insignificant even though most of the coefficients are positive. These simple regressions allow us to consider the global liquidity dynamics as being driven both by local factors and by US monetary policy decisions. These dynamics are thus more than proportional to the initial shock, which amplifies liquidity on the whole. In contrast, UK and EA do not respond significantly to a US monetary shock (columns (1) and (2)).

\section{Global Liquidity and Global Imbalances}

\section{Why the Linkage?}

As noted in the previous section, faced with inflows of global liquidity emerging economies accumulate foreign exchange reserves in order to counter large capital inflows and appreciation pressures on their currencies, and then reinvest these reserves in safe assets like U.S. Treasuries. With regard to this, Caballero (2006) argues that asset supply shortages in emerging economies lead to high demand for US assets and, accordingly, that the asset shortage perspective could explain the low real interest rates and global imbalances.

The data provided by the IMF in its Currency Composition of Official Foreign Reserves database shows that as of 2013 emerging and developing countries held $67 \%$ of total world foreign exchange reserves. And according to this data, these reserves are denominated mainly in USD, EUR, YEN and CAD. To ensure that the issued liquidity can be quickly exchanged without loss in value of the currency, the 
contribution of emerging countries to global liquidity via their foreign exchange reserves will be shown on the asset side of the balance sheet of the EME monetary authorities. If their build-ups of foreign exchange reserves are not followed by sterilization, emerging economy monetary authorities create domestic liquidity through them. They can also directly affect global liquidity by buying assets in foreign markets. By so doing, they increase the demand in these markets for a given supply, which permits liquidity there to increase.

In particular, the accommodative monetary policies of advanced countries since the global financial crisis cause concerns in the capital recipient countries about export competitiveness and abrupt capital outflows, strengthening their incentives for foreign exchange reserve accumulation. And as a result, global imbalances from before the crisis remain with us still. As argued by Kim (2013), although the primary purposes of quantitative easing policies lie in revitalizing the domestic economies of the central banks carrying them out, they also affect other countries through capital flows and exchange rates. He also mentions that, although it might cause emerging economies' current account surpluses to shrink to some extent, it would not necessarily resolve global imbalances if emerging economies increased their foreign exchange reserves to offset appreciation pressures on their currencies. In this context, Choi and Lee (2010) demonstrate the existence of a feedback mechanism between the global monetary expansion and global imbalances. First, the excess global liquidity accounts partly for the large current account surpluses in emerging economies, owing to the positive relationship between global liquidity and net savings rates in emerging economies. Next, if emerging economies increase sterilized interventions in their foreign exchange markets, the capital inflows could end up as foreign exchange reserves instead of leading to domestic investment. This accumulation of foreign exchange reserves finally causes low interest rates in the US, and in this process global imbalances will not be reduced.

Global liquidity might operate as a risk factor threatening financial stability in the global economy through global imbalances. In other words, the expansion in global liquidity constrains monetary policy implementation, creating asset price 
bubbles and strengthening a pro-cyclical credit cycle (Eickmeier, Gambacorta and Hofmann, 2013). In particular, we have experienced volatilities in pro-cyclical global liquidity created endogenously by the private sector. As we have already witnessed, heightened risk appetite boosted private credit creation before the crisis, and stronger risk aversion reduced the aggregate credit volume during the crisis even after central banks increased their liquidity injections (Matsumoto, 2011).

Regional banks play a pivotal role in the endogenous creation of global liquidity through non-core funding involving global banks (Bruno and Shin, 2013; Shin, 2012). Bruno and Shin (2013) construct a model of cross-border capital flows through the interaction between regional and global banks, and show empirically that the leverage cycle of global banks accounts for a substantial portion of total capital flows in the banking sector.

Gourinchas (2012) focuses on 'global liquidity imbalances' rather than 'global imbalances', with liquidity imbalances defined as the mismatches between maturing external liabilities and pledgeable external assets. He points out that gross external positions describe funding conditions more accurately than current account balances do; global liquidity imbalances thus seem to be a more essential concept for explaining global financial stability.

In the following, we examine whether global liquidity has impacts on global imbalances. In relation to global liquidity, the current account deficits of advanced countries and the corresponding surpluses of emerging countries are empirically discussed.

\section{Global Liquidity Heightens Global Imbalances?}

In this section, Panel-VARX models are estimated to investigate the effects of global liquidity on current accounts in both advanced and emerging countries. Real GDP growth, inflation and real effective exchange rates are used as control variables. In the case of emerging countries, global liquidity acts as an exogenous variable. In a parallel fashion, for advanced countries the foreign exchange reserves of emerging countries are assumed as an exogenous variable. In both 


\section{Table 2: Descriptive Statistics}

\begin{tabular}{|c|c|c|c|c|c|c|}
\hline Variable & Definition & Obs. & Mean & S.D. & Min. & Max. \\
\hline \multicolumn{7}{|l|}{ AEs } \\
\hline GLIQ_US & M2-to-GDP(US), \% & 300 & 214.9 & 21.6 & 184.8 & 258.9 \\
\hline GLIQ_G5minusUS & M2-to-GDP(G5 except US), \% & 300 & 433.6 & 73.4 & 325.3 & 533.2 \\
\hline GLIQ_G5 & M2-to-GDP(G5), \% & 300 & 335.8 & 48.0 & 267.0 & 402.0 \\
\hline CA & Current Account-to-GDP, \% & 300 & -0.7 & 2.8 & -6.6 & 5.4 \\
\hline GDP & Real GDP growth, \% & 300 & 1.7 & 2.3 & -9.2 & 5.8 \\
\hline $\mathrm{CPI}$ & CPI growth, \% & 300 & 1.7 & 1.4 & -2.2 & 5.3 \\
\hline REER & Real Effective Exchange Rate & 300 & 102.3 & 15.0 & 72.9 & 133.0 \\
\hline \multicolumn{7}{|l|}{ EMEs } \\
\hline EMFX & EMEs' FX Reserves-to-GDP, \% & 1,200 & 86.5 & 23.6 & 48.3 & 122.0 \\
\hline CA & Current Account-to-GDP, \% & 1,197 & 1.4 & 6.6 & -12.9 & 32.1 \\
\hline GDP & Real GDP growth, \% & 1,183 & 4.5 & 4.0 & -16.3 & 22.0 \\
\hline $\mathrm{CPI}$ & CPI growth, \% & 1,200 & 5.9 & 9.1 & -3.3 & 116.8 \\
\hline REER & Real Effective Exchange Rate & 1,200 & 95.8 & 21.5 & 45.3 & 281.1 \\
\hline
\end{tabular}

Notes: AEs (5): United States, United Kingdom, Euro Area, Japan, Canada; EMEs (20): Argentina, Brazil, Chile, Mexico, Peru, Czech Republic, Hungary, Poland, Russia Federation, Turkey, China, India, Indonesia, South Korea, Malaysia, Philippines, Singapore, Thailand, Israel, South Africa.

Sources: IMF International Financial Statistics and BIS.

cases, the VIX index is also used as another exogenous variable. Accordingly, a reduced form Panel-VARX (p, q) model is specified as follows:

$$
\mathrm{y}_{i t}=A_{1} \mathrm{y}_{i t-1}+\cdots+A_{p} \mathrm{y}_{i t-p}+\mathrm{B}_{0} \chi_{t-p}+f_{i}+\varepsilon_{i t}
$$

where $\mathrm{y}_{i t}$ is the four endogenous variable vector $\left(C P I_{i t}, R E E R_{i t}, G D P_{i t}, C A_{i t}\right), x_{i t}$ the exogenous variables $\left(G L I Q_{t}\right.$ or $\left.E M F X_{t}, V I X_{t}\right), f_{i}$ the individual fixed effect, and $\varepsilon_{i t}$ the error term. 
In this model, $C P I_{i t}$ is the $C P I$ growth rate (year-on-year) of individual country $\mathrm{i}$ at time t, REER $R_{i t}$ the real effective exchange rate, $G D P_{i t}$ the real $G D P$ growth rate (year-on-year), $C A_{i t}$ the current account-to-nominal $G D P$ ratio, and $G L I Q_{t}$ global liquidity. Regarding global liquidity, GLIQ US denotes the M2-to-nominal GDP ratio in the US, GLIQ G5minusUS the sum of the aggregate M2-to-GDP ratios in the UK, the Euro area, Japan and Canada, and GLIQ G5 the sum of the aggregate M2-to-GDP ratios in the US, the UK, the Euro area, Japan and Canada. More precisely, GLIQ US or GLIQ G5minusUS or GLIQ G5 are employed as the exogenous variable for emerging countries, while EMFX (the ratio of FX Reserves to GDP among EMEs) is used for advanced countries. Table 2 shows the descriptive statistics of the variables used in the estimation. Our dataset covers five advanced (United States, United Kingdom, Euro area, Japan and Canada) and 20 emerging (Argentina, Brazil, Chile, Mexico, Peru, Czech Republic, Hungary, Poland, Russia Federation, Turkey, China, India, Indonesia, South Korea, Malaysia, Philippines, Singapore, Thailand, Israel and South Africa) countries. The sample period ranges from the first quarter of 1999 through the fourth quarter of 2013.

The model incorporates the $p$ lags of the endogenous variables and the $q$ lags of the exogenous variables. Depending upon the exogenous variable, $p=4, q=1$ (GLIQ_US, GLIQ_G5minusUS and GLIQ G5) and p=2, $\mathrm{q}=0$ (EMFX) are used. Alternative specifications with various lag structures are also estimated for a robustness check. The Helmert procedure is employed to remove the individual fixed effects, as in Arellano and Bover (1995) and Love and Ziccino (2006). Through Helmert's transformation using the forward mean differencing method, all variables are included in their first differences, and the explanatory variables and the error term can be orthogonal.

For the multiplier analysis, equation (10) can be represented with the lag operator $\mathrm{L}$ as in equation (11):

$$
\mathrm{y}_{i t}=A(L) \mathrm{y}_{i t}+B(L) \chi_{t}+\varepsilon_{i t},
$$


where $A(L)=A_{1} L+\cdots+A_{p} L^{P}$ and $B(L)=B_{0}+\cdots+B_{q} L^{q}$. Now we get the multiplier form of the model by simply inverting equation (11) as follows:

$$
\mathrm{y}_{i t}=A(L)^{-1} B(L) \chi_{t}+A(L)^{-1} \varepsilon_{i t}
$$

The responses of the endogenous variables to a unit change in the exogenous variable are thus obtained by the following lag polynomial:

$$
\Phi(L)=A(L)^{-1} B(L)
$$

Figure 3 presents the responses to an increase in global liquidity with bootstrapped confidence bands indicating the 0.16 and 0.84 percentiles of the draws. We focus on the response of the current account to an increase in global liquidity. In the cases of GLIQ US, GLIQ G5minusUS and GLIQ G5, as shown in Figure 3, the responses of current accounts are immediately negative, but then become positive. And the increases in global liquidity lead to initial positive effects on output growth of emerging economies. These results indicate that output growth is positively associated with easing monetary policies of EMEs accommodating expansionary monetary policies of AEs. The depreciation of REER, which might be driven by sterilized interventions, can contribute to current account surpluses of emerging countries. Meanwhile, as shown in Figure 4, an increase in EMFX reduces the current accounts of advanced countries for a considerable time, with the impact slowly disappearing after it has peaked. As EMEs have invested their foreign exchange reserves in the financial assets of AEs, consequent low interest rates cause rising prices and current account deteriorations of advanced economies.

In short, we find that an increase in AEs' monetary liquidity has a positive effect on EME's current accounts, while an expansion in EMEs' FX reserves negatively affects the current accounts of AEs, indicating that global liquidity does in the end heighten global imbalances. 
Figure 3: Responses of EMEs to Global Liquidity

$\langle$ Global Liquidity (US)〉
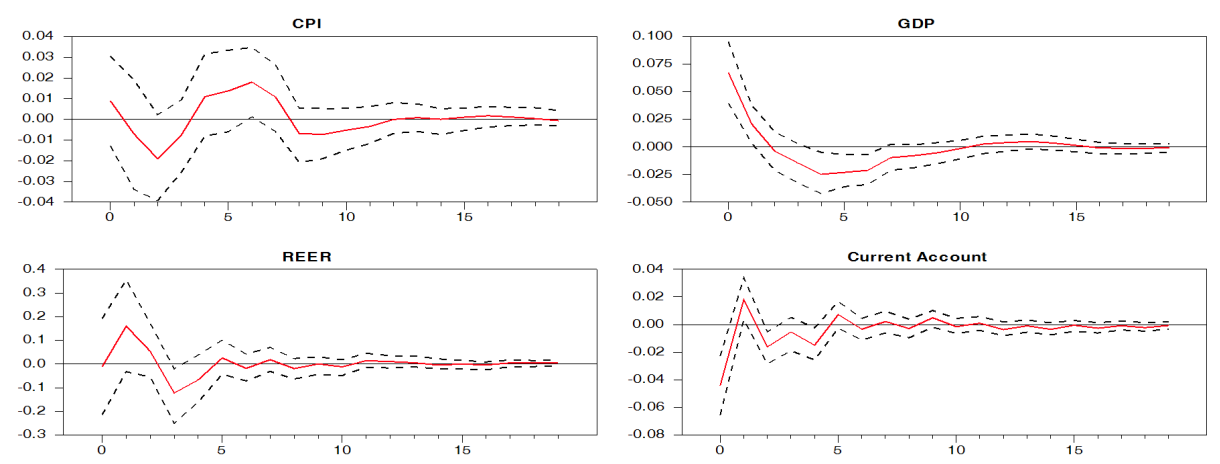

$\langle$ Global Liquidity (G5minusUS) 〉
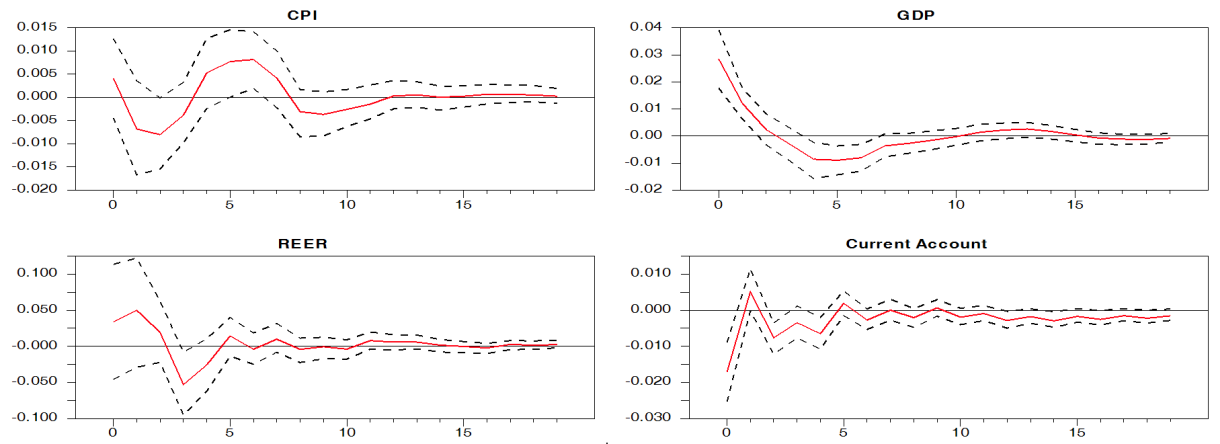

$\langle$ Global Liquidity (G5)〉
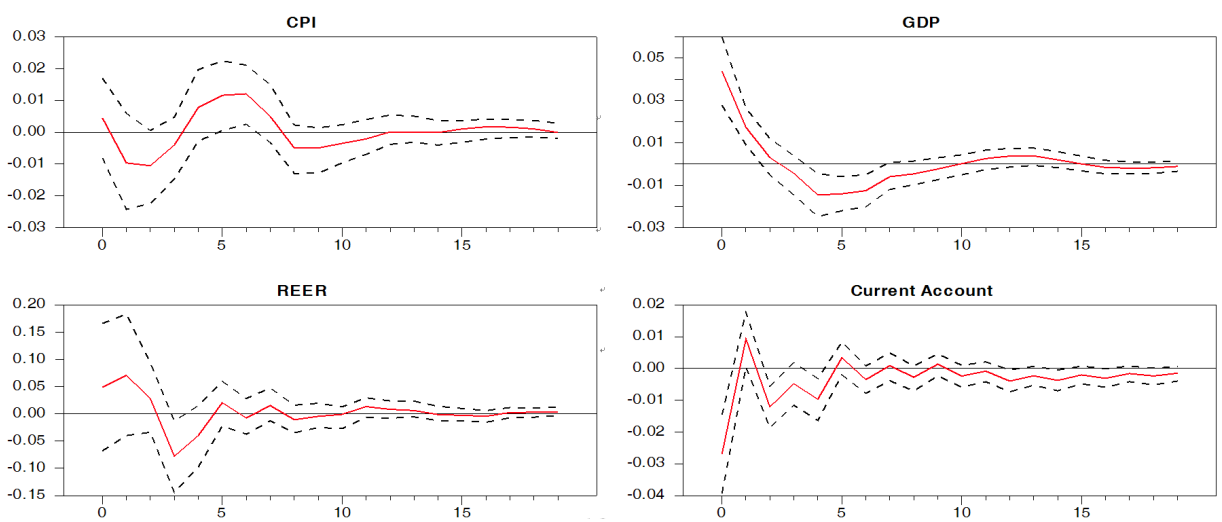

Notes: All figures show the responses of EMEs to an increase of one percentage point in global liquidity (M2-to-GDP ratio). 
Figure 4: Responses of AEs to EMEs' FX Reserves
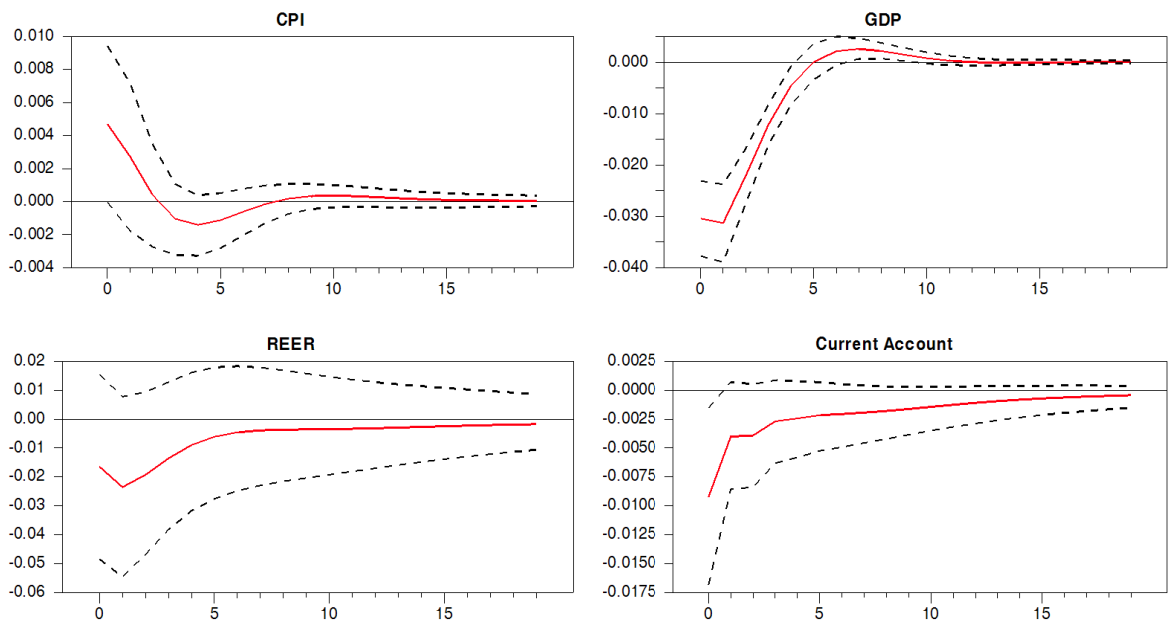

Notes: All figures show the responses of AEs to an increase of one percentage point in EMEs' FX Reserves (FX Reserves-to-GDP ratio).

\section{Conclusion}

This paper discusses how global liquidity is amplified in response to a US monetary policy shock, and whether global liquidity has effects on global imbalances. To this end we estimate regression and Panel-VARX models using data from the G5 (United States, United Kingdom, Euro area, Japan and Canada) and 20 emerging countries. The empirical results show that the dynamics of global liquidity are significantly affected by a US monetary shock, and that the effects on global imbalances of global liquidity are significant. The foreign exchange reserves of emerging economies are also found to play a significant role driving global imbalances.

Global liquidity, defined in this paper as the sum of the broad monetary aggregates (M2 or M4) in advanced countries so as to reflect an aggregate monetary policy, follows dynamics that are not just reflections of specific local conditions. It is also affected by the responses of other central banks to US monetary policy. These central banks react in order to stabilize their exchange rates against the US dollar and maintain their price competitiveness. The 
synchronization of economic cycles, and the real and financial inter-linkages between the US and other advanced countries, also contribute to explaining central bank reactions when US monetary policy changes. In this regard, US monetary policy can be considered a leading indicator of future global liquidity dynamics. These global liquidity dynamics moreover have a significant impact on global imbalances. The global financial instability experienced during the global financial crisis might have been attributable to global imbalances, considering that global imbalances could have led to the low interest rates, search for yield, higher leverage and subsequent vulnerabilities in the global financial system. Further study is needed to confirm the relationship between global imbalances and global financial instability. 


\section{References}

Arellano, M., and O. Bover (1995), “Another Look at the Instrumental Variable Estimation of Error-Components Models," Journal of Econometrics, Vol. 68, pp. 29-51.

Barnett, A., and R. Straub (2008), "What Drives U.S. Current Account Fluctuations?” ECB Working Paper, No. 959.

Bernanke, B. (2005), "The Global Saving Glut and the U.S. Current Account Deficit," Remarks at the Homer Jones Lecture, St. Louis, Missouri, April 14.

Bernanke, B. (2007), "Global Imbalances: Recent Developments and Prospects," Bundesbank Lecture, Berlin, Germany, September 11.

Bruno, V., and H. S. Shin (2013), "Capital Flows, Cross-Border Banking and Global Liquidity,” NBER Working Paper, No. 19038.

Caballero, R. J. (2006), "On the Macroeconomics of Asset Shortages," NBER Working Paper, No. 12753.

Caballero, R. J., E. Farhi, and P.-O. Gourinchas (2008), "Financial Crash, Commodity Prices and Global Imbalances,” NBER Working Paper, No. 14521.

Choi, W. G., and I. H. Lee (2010), "Monetary Transmission of Global Imbalances in Asian Countries," IMF Working Paper, No. 214.

Chung, K., S. Kim, H. Park, C. Choi, and H. S. Shin (2014), Volatile Capital Flows in Korea, Palgrave Macmillan.

Cooper, R. N. (2006), "Living with Global Imbalances: A Contrarian View," Journal of Policy Modeling, Vol. 28, No. 6, pp. 615-627.

Djigbenou, M.-L. (2013), "Determinants of Global Liquidity Dynamics," mimeo.

Dooley, M. P., D. Folkerts-Landau, and P. Garber (2004), "The Revived Bretton Woods System: The Effects of Periphery Intervention and Reserve Management on Interest Rates and Exchange Rates in Center Countries," NBER Working Paper, No. 10332. 


\section{$21 \quad$ BOK Working Paper No.2015-23(2015.9)}

Draghi, M., and V. Constâncio (2013), "Introductory Statement to the Press Conference (with Q \& A)," European Central Bank.

Ehrmann, M., and M. Fratzscher (2009), "Global Financial Transmission of Monetary Policy Shocks," Oxford Bulletin of Economics and Statistics, Vol. 71, No. 6, pp. 739-759.

Eickmeier, S., L. Gambacorta, and B. Hofmann (2013), "Understanding Global Liquidity," BIS Working Paper, No. 402.

Feldstein, M. S. (2008), "Resolving the Global Imbalance: The Dollar and the U.S. Saving Rate,” NBER Working Paper, No. 13952.

Gagnon, J. E. (2012), "Global Imbalances and Foreign Asset Expansion by Developing Economy Central Banks," PIIE Working Paper, No. 12-5.

Gourinchas, P.-O. (2012), “Global Imbalances and Global Liquidity,” mimeo.

IMF, "Currency Composition of Official Foreign Reserves Database - COFER."

IMF (2013), “Global Liquidity - Credit and Funding Indicators," IMF Policy Paper.

Kazyi, I. A., H. Wagan, and F. Akbar (2013), "The Changing International Transmission of U.S. Monetary Policy Shocks: Is there Evidence of Contagion Effect on OECD Countries," Economic Modelling, Vol. 30, pp. 90-116.

Kim, C. (2013), "Global Liquidity Waves: Challenges for the Global Economy," Opening Address at BOK International Conference.

Love, I., and L. Zicchino (2006), "Financial Development and Dynamic Investment Behavior: Evidence from Panel VAR," Quarterly Review of Economics and Finance, Vol. 46, pp. 190-210.

Matsumoto, A. (2011), “Global Liquidity: Availability of Funds for Safe and Risky Assets," IMF Working Paper, No. WP/11/136.

Shin, H. S. (2012), "Global Banking Glut and Loan Risk Premium, Mundell-Fleming Lecture," IMF Economic Review, Vol. 60, No. 2, pp. 155-192. 


\section{$<$ Abstract in Korean $>$}

\section{글로벌 유동성이 글로벌 불균형에 미치는 영향}

Marie-Louise DJIGBENOU-KRE*, 박하일**

본고는 미국의 통화정책 변화가 여타 선진국 통화정책에 파급되는지 여부를 살펴보고, 선진국의 통화량 확대와 신흥국의 외환보유액 확충이 글로벌 불균형에 미치는 파급효과를 신흥국과 선진국으로 구분하여 각각 분석하였다. 분석 결과 미국의 통화량 변동이 여타 선진국의 통화량 변동에 영향을 미치는 가운데 선진국의 통화량 변동은 신흥국의 경상수지에 유의한 영향을 미치고, 신흥국의 외환보유액 축적도 선진국의 경상수지에 영향을 미쳐 글로벌 불균형을 지속시키는 역할을 하는 것으로 나타났다.

핵심주제어 : 글로벌 유동성, 글로벌 불균형, 패널 VARX, 미국의 통화정책 충격, 파급효과

JEL Classification: E51, F30, F33

\footnotetext{
* Banque de France 이코노미스트

** (전) 한국은행 경제연구원 선임연구원, (현) 경희대학교 무역학과 조교수

본 논문은 박하일 교수가 한국은행 경제연구원에 근무할 당시 완성된 것이며, 연구내용은 집필자의 개인 의견이며 한국은행 및 프랑스은행(Banque de France)의 공식견해와는 무관합니다. 따라서 본 논문의 내용을 보도하거나 인용할 경우에는 집필자명을 반드시 명시하여 주시기 바랍니다.
} 